\title{
Sustainable Biofuel Production using Lignocellulosic Biomass as a Raw Material
}

\author{
Vatsla Gupta, Nishant Veer Vikram Singh, Aarushi Shukla, \\ Namita Singh, Santosh Kumar Mishra*
}

Department of Biotechnology, IMS Engineering College, Ghaziabad, U.P. India

*Corresponding author

\section{Keywords}

Biomass, Biofuel,

Bioethanol,

Lignocellulosic,

Biochemical,

Alcohols

Article Info

Accepted:

22 June 2020

Available Online:

10 July 2020

\section{A B S T R A C T}

In the past few decades enormous research are going in the area of biofuel production due to fast depletion of petroleum product and several environmental issues biofuel such as ethanol emerged as alternative energy resource produced through fermentation process. Lignocellulosic biomass is considered as most economical, easily available and highly renewable natural resource in the agricultural rich countries. Technical advancement in past few decades provides an efficient way to use lignocelulosic biomass for biofuel production for sustainable energy requirement. Lignocellulosic biomass is used in the production of ethanol, which can be considered as an energy source alternative to petrol (fossil fuel). The conversion of lignocellulosic biomass into energy source involves mainly two process i.e. hydrolysis and pre-treatment of lignocellulosic biomass. Use of alternative energy sources can be an environmental friendly solution to meet our present challenges. Biofuel derived from renewable energy sources such as libnocellulossic biomass represent the clean fuel alternative to overcome the energy crisis globally in eco-friendly and sustainable manner. This review highlighted the recent research in the area of biofuel production using agricultural waste are its impact on the sustainable biofuel production.

\section{Introduction}

Excessive use of fossil fuels results in environment pollution especially in terms of generation of greenhouse gases. The various natural sources of energy likes wind, water, sun, biomass and geothermal heat can be utilizes for fossil fuel production of petroleum-based food can be replaced by biomass fuel as biochemical, biodiesel, bio hydrogen etc. Biofuel is power source that is produced through a series of bioconversion processes by using biomass as a starting substrate. Examples of biofuel are ethanol (produced from corn, sugarcane, switch grass, water hyacinth), biodiesel (vegetable oils, animal fats), green diesel (algae and other plant sources) and biogas. (Ahmad et.al, 2011)

Majoroty of biomass sources used for the production of biofuel including Grains and starch crops (like sugarcane, wheat, corn, beetroot, etc.), agricultural wastes (like Corn 
Stover, wheat and rice straw, etc.). In present scenario lignocellulosic materials and genetically engineered plants are used for high yield of biofuel. Microalgae are also potentially efficient candidate for the valuable biofuel production at low cost. Further cost could be reduced by using genetic modification in the metabolic pathways to increase growth rates. In recent years microalgal are constantly being used as promising feedstock for biofuel production because microalgae having capability to store solar energy into a biochemical energy (Correa et al., 2020 \& Jeslin et al., 2020).

Currently the scheme of production of biofuel involves various phenomenon and biological reaction as follows:-

Unlike fossil fuel, ethanol is a sustainable energy source produced through fermentation of sugars. In US gasoline is partially replaced by ethanol. Since 1980s ethanol that is generated from corn has been used in gasohol (mixture of petrol and ethanol) or oxygenated fuels that is used in internal combustion engine. These gasoline petrol fuels consist of $10 \%$ ethanol by volume. As a result, about 4540 million litres of fuel is now consumed by the US transportation sector which is about $1 \%$ of global gasoline consumption. By using ethanol-blended fuel for automobiles we can remarkably reduce greenhouse gas emission by use of petroleum based fuels. (Sun et al., 2002). Ethanol is also a safer substitute to methyl tertiary butyl ether (MTBE), the prevailing additive to gasoline used to provide cleaner combustion (Hamid, et al., 2004). MTBE is a noxious chemical compound which pollutes the groundwater. The beginning of regulatory action has been recently announced to eliminate the use of MTBE in gasoline by the US Environmental Protection Agency. However, as compared to conventional fuel aka fossil fuel, ethanol as biofuel is comparatively expensive. Therefore production of biofuel from cheapest route to replace it by conventional fuel in all aspects including several environmental issues as well as lowering of fuel prices. Generally rice, wheat, corn straws as well as sugarcane bagasse considered as a major agro-waste feedstock for biofuel production. Agricultural waste includes majorly lignocellulosic waste. It include grasses (switch grass), sawdust, woodchips etc. (Patanaik, et al., 2019). Biofuels having several advantages over convention fuel such as, it is a renewable source, there is less emission of carbon, reduce our reliance on fossil fuel, biofuel are more readily available \& sustainable and posses less risk to human health. The aim of this review is to present a brief and recent overview of the available \& accessible technologies for biofuel such as bioethanol production using major lignocellulosic agrowaste. In this review we highlighted the different types of processes that involves in the conversion of biomass into biofuel and present status as well as recent advances area of bioenergy production using lignocellulosic biomass.

\section{Current status of biofuel production using lignocellulosic biomass from agricultural waste}

There are many sources which can be grabbed from nature as dry matter of plants (majorly includes lignocellulosic biomass) and they are helpful to produce biofuel. These sources are readily available in sufficient quantity in nature. If we consider only lignocellulosic biomass so they composed of carbohydrate polymers i.e. cellulose, hemicelluloses etc. (Chandra, et al., 2012)

From a long time there is lack of awareness about many other available resources for biofuel production and industries as well as scientists working in this field underestimated the power of many raw materials, switchgrass 
is one of them. For estimating the quantitative efficiency about production of biofuel there should be a measurement of how much land is available for the production of switch grass within a duration. According to the data available raw materials can produce 5 tons or 10 tons per acre in several regions depending on the availability of resources. Yet there is a chance that in upcoming years biofuel production will be majorly depend on other resources and will grow with the large level. (Mitchell, et al., 2012.). Switch grass is significantly recognised as perennial grass native to the North America. Switchgrass is used for its several properties like it gives high productitvity and shows adaptability and potential ease with existing agricultural operations.

There are countable ways to produce biofuel by switchgrass but to increase quantitative as well as qualitative efficiency chemical process and chemical components are used during the production.(David et al 2010)

Hyacinth which is a monocotyledonous freshwater aquatic plant and it is native of Brazil and Equador region are also being constantly used for production of biofuel in several countries where it is easily available. There are major reasons why water hyacinth is included as an efficient raw material for bioenergy resource in biofuel production. And those reasons are including naturally grown vegetation, preferably perennials plant contains low lignin content but high volume of cellulose per unit of dry matter and therefore this is easily degradable. It will not be the problem for other local plants as competitor for arable crop plants for space, light and nutrients etc. And also resists pests, insects and disease. Hycinth is also not prone to genetic pollution by cross breeding with cultivated food crops (Bhattacharya, et al., 2010).
A generalized process for the production of biofuel by using agricultural waste as raw material is mentioned in Figure 3

If soyabean is going to be considered as a another raw material then there is the problem raised about this crop that it is also included as a resource of human food material. Soyabean can be converted into the useful form (biofuel) by application of several chemical processes and one of them can be known as trans-esterification which gives the methyl or ethyl esters (biodiesel) as a product and glycerine as a by-product. This reaction includes reaction of vegetable oils or animal fats with methanol or ethanol in the presence of sodium hydroxide (which acts as a catalyst). There are many other resources too for production of biofuel as they are not so famous and readily used. Camelna and Jatropha are those raw materials. These flowering plants are advantageous more if it is compared to the seed based fuels like soy because they are adaptable for the dry areas and this is the main advantage. These plants will not cover those land areas which can be used for basic agricultural production (Gheewala et al., 2012)

\section{Lignocellulosic waste in biofuel production}

Lignocellulosic waste is a renewable feedstock for a production of biofuel. In the Lignocellulosic waste different types of waste material included like corn stover, sugarcane bagasse, straw, saw mill, paper mill, switch grass etc.

Lignocellulosic biomass used in a second generation biofuel production from cellulose, hemicellulose and lignin. Lignocellulosic is a very important option for reducing use of food and energy security, it is replace by sugarcane and maize. In Lignocellulosic material different type of feedstock present but that have gain more attention on corn 
stover, rice husk, wheat straw and sugarcane bagasse. India is among major cultivators of banana and banana's pseudo stem could be exploited for the production of biofuel by extracting its cellulosic material by pretreatment processes (Ingale, et al., 2019). As second generation biofuel is solely agriculture based so problem arising during its scale up is majorly of land on which the crops were grown. Also if waste are used the major challenge is to extract cellulose and hemicelluloses from raw material. This is the main reason why the scale up of biofuel from agricultural waste is still under research. Corn stover has an estimated cellulose, hemicellulose, lignin, protein and ash contain of $33-43 \%, 20-34.5 \%, 8-41.1 \%, 5 \%$ and $4 \%$ respectively (Panagiotou,, et al 2007). Estimated rice husk composition to be cellulose $(28.6 \%)$, hemicellulose $(28.6 \%)$, lignin (24.4\%) and extractive matter (18.4\%). The biochemical compostion of sugarcane bagasse is $40 \%$ cellulose, $25 \%$ hemicellulose and $10 \%$ of other extractive. Wheat straw's cellulose, hemicellulose and lignin content is estimated to be $33-40 \mathrm{w} / \mathrm{w} \%, 20-25 \mathrm{w} / \mathrm{w} \%$ and $15-20 \mathrm{w} / \mathrm{w} \%$ respectively. The substantial cellulose and hemicellulose content of Lignocellulosic biomass used as necessary source of sugars of the production of biofuel. (Kim, et al., 2011)

Purpose grown energy crops such as vegetative grasses and short rotation forests have great potential for the production of second generation biofuel. These vegetative grasses includes switch grass, miscanthus, big blustem, Altaiwildye, alfaalfa and yellow sweet clover. Switch grasses and miscanthus have also received a great deal of attention. Lignocellulosic biomass undergoes pretreatment for extraction of starch and cellulose component from the feedstock. Various methods of pretreatment are mentioned in the Figure: 5
Hydrolysis of starch and cellulose is then takes place for conversion of complex molecules into simple one. The most commonly used methods are concentrated hydrochloric acid hydrolysis, dilute acid hydrolysis and enzymatic hydrolysis. The detoxification of hydrolysate by physical chemical and biological method prior to fermentation is done to remove inhibitor substance from the medium.(Olsson et al, 1996). After conversion of lignocelluloses to reducing sugars, fermentation of sugar into ethanol is not a difficult task. There are 3 different techniques used in this context-

Separate hydrolysis and fermentation(SHF)

Direct microbial conversion(DMC)

Simultaneous saccharification and fermentation(SSF)

However SSF is widely employed for production of biofuel at large scale processes (Wright, Wyman, and Grohmann 1988)

\section{Advantages of lignocellulosic waste in biofuel production}

Biofuel production using lignocellulosic biomass having several advantages over fossil fuel. It also reduce fossil fuel dependence and green house gas emission as well as reduction in consumption of petroleum products. It is highly stable, low in cost and good option for industrial production of biofuel. Biomass obtained from food wastes and crop wastes can be used for biofuel production. So, there is no need to cover extra land for production of raw material. Biofuel is also useful in the elimination of the problem associated with disposal of crop waste.It is beneficial for both rural and urban areas in terms of energy, security reason, environmental concern, employment opportunities, agricultural development, foreign exchange saving etc. 


\section{Large scale production of biofuel}

Large scale production of biofuel mainly focuses on utilization of agricultural waste as well as to reduce the production cost per kilogram yield as compared to other biofuel sources. Its success depends on the feasibility of operation of plant process and availability of cheap raw material (Ulgiati et al., 2001). The various agro-waste used for biofuel production and yield of biofuel is summarised in table-1

United States and Brazil were major producers of biofuel worldwide in 2018. In 2017 US produces 16 billion gallons of ethanol becoming world's largest producer of ethanol. Majority of ethanol produced using corn and sugarcane as raw material in US and Brazil respectively (Singh et al., 2019)

Although various countries like USA, Brazil, China, South Africa, Japan, India etc are the major producers of biofuel still some hurdles are in the way to commercialize the biofuel at large scale and replacing the conventional fossil fuel. One of the greatest challenge is to design the engines of machineries' that are compatible for biofuel. Another hurdle is cost as compared to conventional fuel. In current scenario countries are working on modification of engines to make it compatible for biofuel. Another challenge is technological advancement for production process.

As biofuel production process include four stages namely pretreatment of raw material, hydrolysis followed by fermentation and lastly saccharification to produce bioethanol the 4 kinds of operational reactors for this purpose are given in table-2. However in semi continuous system there is high risk of contamination and also huge investment is required (Jain \& Chourasia, 2014). The fed batch system is mostly used for production purposes.

\section{Agro-waste in Algal Biomass based biofuel production}

The recent research focusses on usage of algal biomass for production of bioethanol using enzyme hydrolysis pretreatment followed by fermentation. Biofuel can be produced by micoalgae as well as macroalgae but macroalgae can only produce gaseous fuel due to low lipid content. Microalagae are rich in carbohydrate, protein and lipid and concentration varies according to conditions and strains used.(Kumar et al., 2016). However production of biofuel from algal biomass is known as third generation biofuel and considerable amount of research is still going in this area (Gaurav et al., 2017). Different types of biofuel obtained from microalgae is summarised in the table- 3

Anaerobic digestates deriving from agrowaste or sewage sludge treatment induced a more than $300 \%$ increase in lipid production per volume in Chlorella vulgaris cultures grown in a closed photo bioreactor, and a strong increase in carotenoid accumulation in different microalgae species. Conversely, a digestate originating from a pilot scale anaerobic up flow sludge blanket (UASB) was used to increase biomass production when added to an artificial nutrientsupplemented medium (Zuliani et al., 2016). Microalgae can produce high oil (more than 300 times) than other existing resources such as terrestrial plants. The renewable sources include wood, plants, agro-waste, fruit pulps and other waste materials with nutrients. The use of biomass based bioenergy or biofuel is gaining public attention due to their environment friendly aspects. Earlier the biofuel was produced from food and non food crops which puts pressure on land resource. To circumvent such negative impacts, scientific communities have explored the use of microalgae for production of biofuels (Katiyar et al., 2017) 
Table.1 Comparative table showing the yield of biofuel production by using various agroindustrial by products as raw material

\begin{tabular}{|l|l|l|l|l|}
\hline S.No. & Raw Material & $\begin{array}{l}\text { Major } \\
\text { Constituent }\end{array}$ & Yield(Gal/Ton) & References \\
\hline $\mathbf{1 .}$ & Barley & starch & $70.1-77.5$ & Qureshi, et al $(2010)$ \\
\hline $\mathbf{2 .}$ & corn & starch & $98.0-98.6$ & Capunitan, et al $(2012)$ \\
\hline $\mathbf{3 .}$ & Grain sorghum & starch & $81.8-105.1$ & Ananda, et al $(2011)$ \\
\hline $\mathbf{4 .}$ & sugarbeet & sugar & $19.8-21.6$ & Panella, L. $(2010)$ \\
\hline $\mathbf{5 .}$ & sugarcane & sugar & $15.5-18.6$ & Hoefnagels, et al(2010) \\
\hline $\mathbf{6 .}$ & wheat & starch & $86.1-88.7$ & Mueller, et al $(2011)$ \\
\hline $\mathbf{7 .}$ & Sugarcane bagasse & cellulose & 111.5 & De Albuquerque, et al $(2014)$ \\
\hline $\mathbf{8 .}$ & switchgrass & cellulose & 96.7 & Shen, Hui, et al $(2013)$ \\
\hline $\mathbf{9 .}$ & Hardwood sawdust & cellulose & 100.8 & Dagnino, et al $(2013)$ \\
\hline
\end{tabular}

Table.2 Comparative table showing various mode of Bioreactor operation for biofuel production (Caylak et al, 1998 \& Maiorella et al., 1981)

\begin{tabular}{|c|c|c|}
\hline Operation & Activities during operational process & Advantage \\
\hline Batch & $\begin{array}{l}\text { Substrate and yeast culture are charged into } \\
\text { bioreactor together with nutrients. }\end{array}$ & $\begin{array}{l}\text { Investment cost low, no skilled labour } \\
\text { required, sterilization and } \\
\text { management of feedstock is also easy }\end{array}$ \\
\hline Continuous & $\begin{array}{l}\text { Feed containing substrate, culture, and required } \\
\text { vitamins and minerals are fed at constant interval } \\
\text { in agitated vessel. The product is taken from top. }\end{array}$ & Suitable for large scale production \\
\hline Fed batch & Combination of batch and continuous system. & $\begin{array}{l}\text { Intermittent feeding of substrate } \\
\text { prevent inhibition and catabolite } \\
\text { repression. } \\
\text { Most commonly used operation for } \\
\text { biofuel production at large scale. }\end{array}$ \\
\hline $\begin{array}{l}\text { Semi } \\
\text { continuous }\end{array}$ & $\begin{array}{l}\text { Small portion of culture is withdrawn at intervals } \\
\text { and fresh medium is added to system }\end{array}$ & $\begin{array}{l}\text { No need of separate inoculum vessel. } \\
\text { Not much control is required. }\end{array}$ \\
\hline
\end{tabular}

Table.3 Different forms of bioenergy from microalgae

\begin{tabular}{|l|l|l|}
\hline $\begin{array}{l}\text { Component used in biofuel } \\
\text { production }\end{array}$ & Route of production & Type of biofuel \\
\hline Biological hydrogen & Direct & Hydrogen gas \\
\hline Hydrocarbons & Hydrocracking and distillation & Oil refinary product \\
\hline Lipids & Transesterification & Biodiesel \\
\hline Carbohydrates & Fermentation & Biohydrogen,bioethanol, Biobutanol \\
\hline Whole biomass & $\begin{array}{l}\text { Anaerobic digestion } \\
\text { Hydrothermal liqifaction } \\
\text { Pyrolysis,gasification,direct } \\
\text { combustion }\end{array}$ & $\begin{array}{l}\text { Biogas, Biocrude } \\
\text { Energy rich gas mixture, } \\
\text { Syngas }\end{array}$ \\
\hline & & \\
\hline
\end{tabular}


Table.4 Comparison between forecasted production and production needed for Sustainable Debvelopment Scenarion( SDS) by various countries (IEA 2019, Tracking Transport)

\begin{tabular}{|l|c|c|}
\hline Country & $\begin{array}{l}\text { Forecasted biofuel production } \\
\text { (annually) 2019-2024 }\end{array}$ & $\begin{array}{l}\text { Production } \\
\text { SDS (2019-2030) }\end{array}$ \\
\hline United States & $1 \%$ & $6 \%$ \\
\hline European Union & $0.50 \%$ & $8 \%$ \\
\hline Brazil & $3.50 \%$ & $6 \%$ \\
\hline India & $11 \%$ & $22 \%$ \\
\hline China & $16 \%$ & $17 \%$ \\
\hline ASEAN & $9 \%$ & $8 \%$ \\
\hline
\end{tabular}

Fig.1 Schematic diagram showing the process of production of second generation biofuel

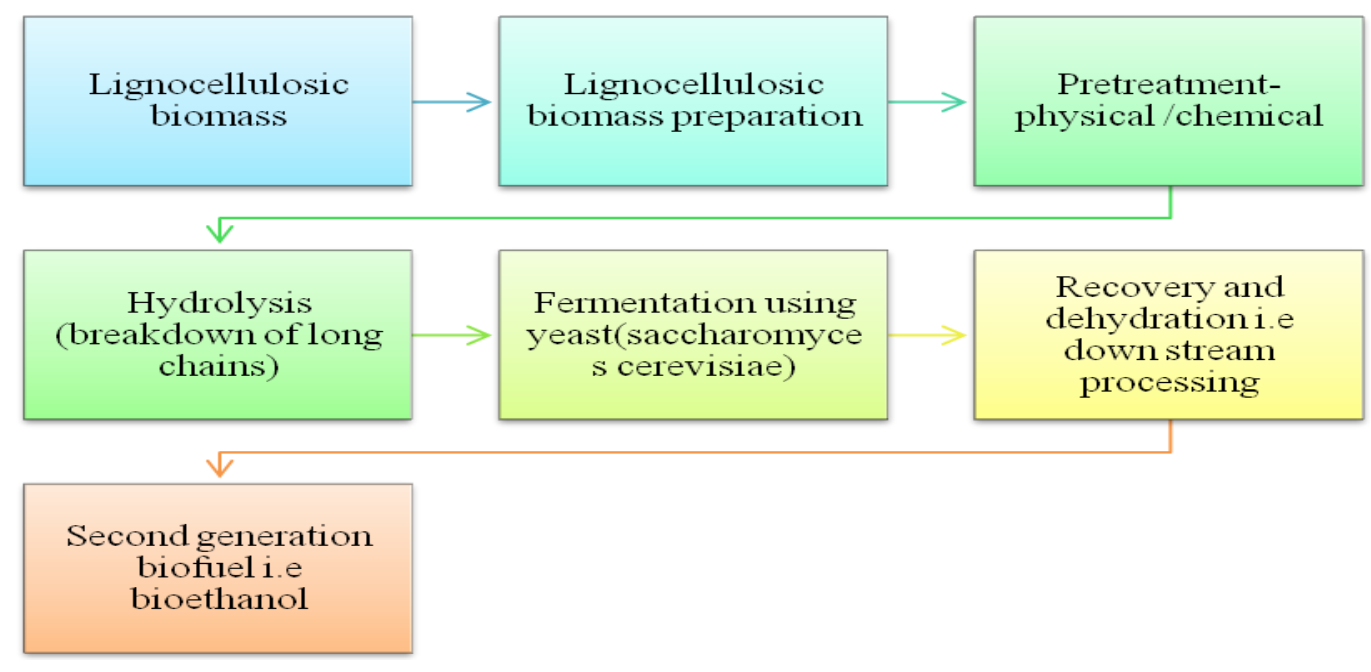

Fig.2 Status of Biofuel production between 2001-2018 using agro-waste

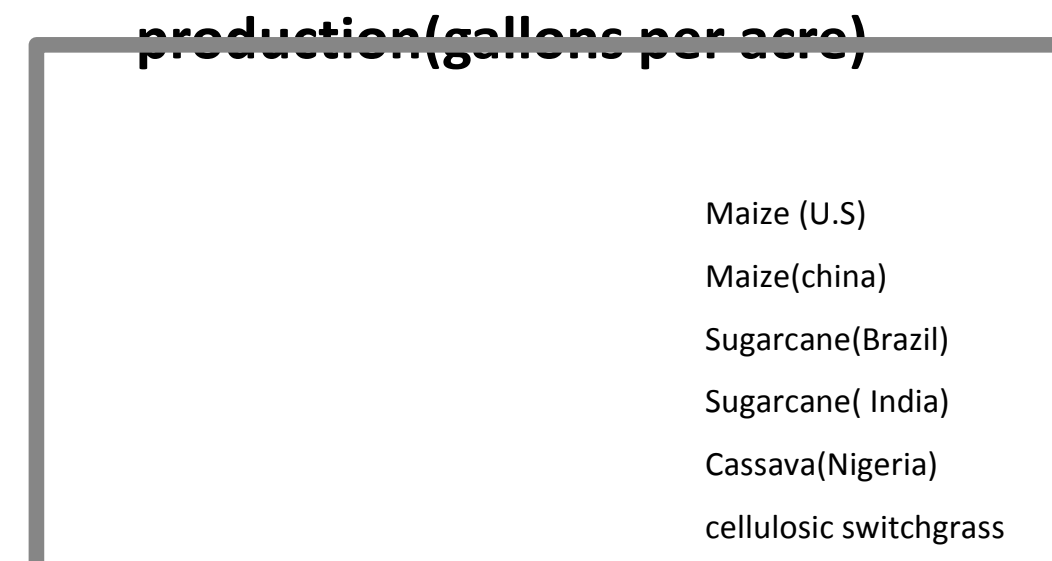

Source: Monthly Energy Review, April 2019, Energy Information Administration (EIA) 
Fig.3 Schematic diagram showing the conversion of agro-waste for biofuel production



Fig.4 Different lignocellulosic raw materials used in biofuel production

No Figure

Fig.5 Pre treatment processes of lignocellulosic waste

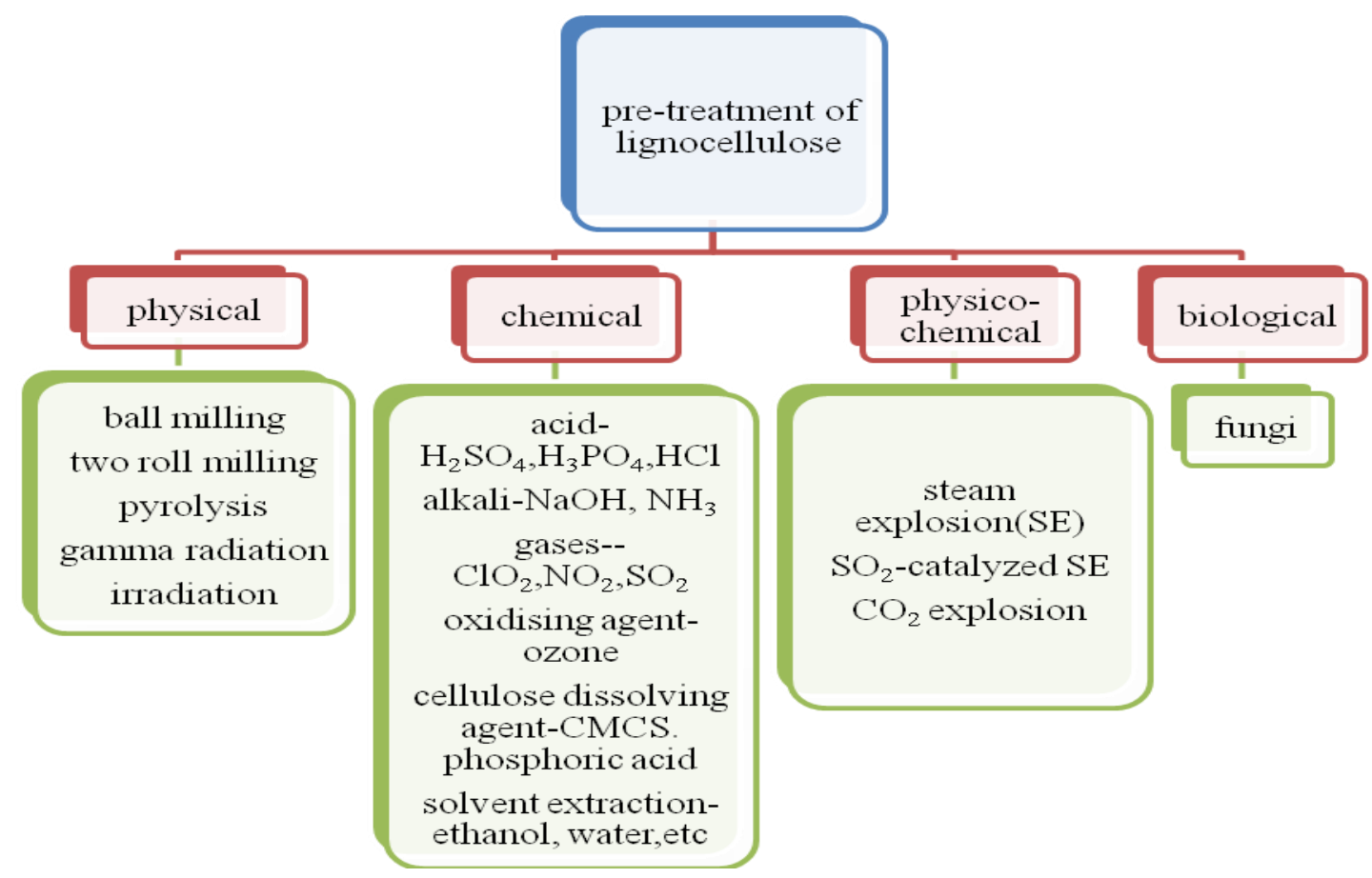


Fig.6 Major Biofuel producing country and production capacity (2018)

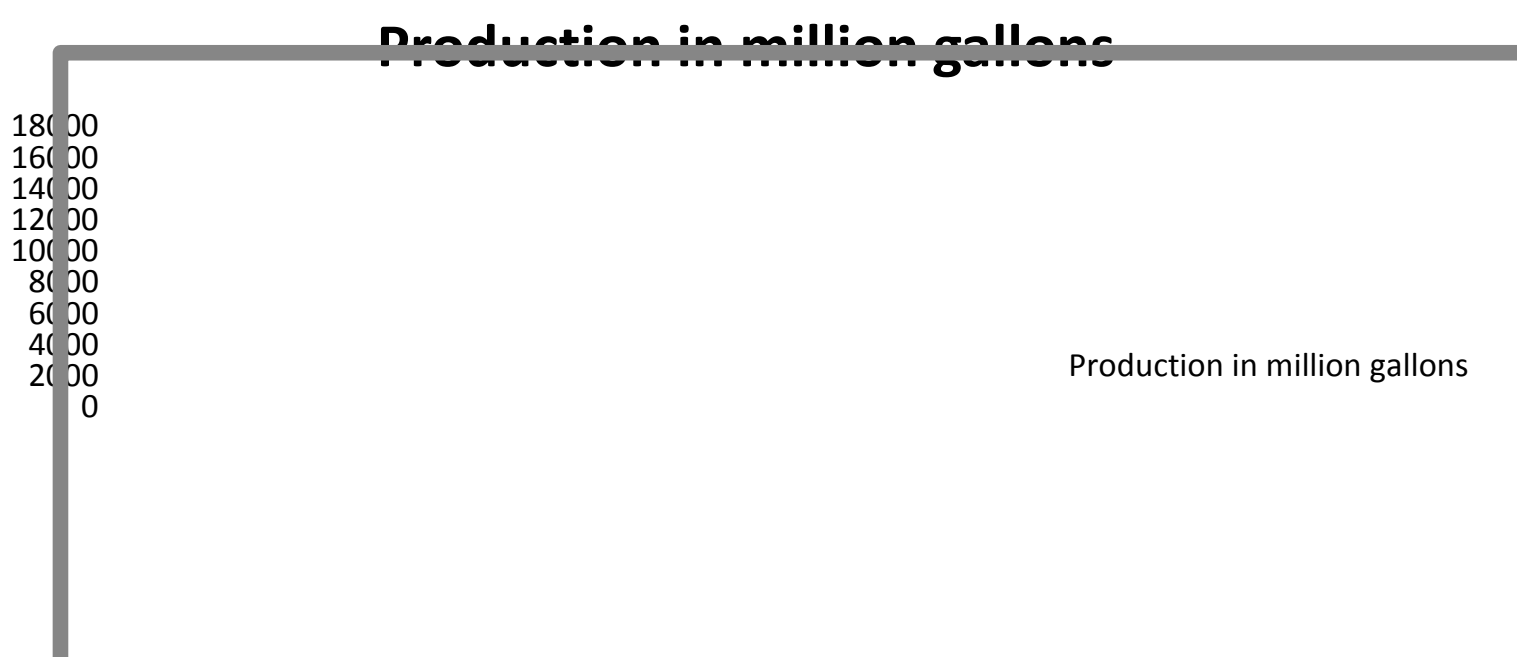

Recent advancement in production of biofuel

As the demand of biofuel especially for transport purpose increasing, there is a need to develop advance techniqes for production of biofuel to ensure sustainable growth of our society. Different approches worldwide are towards biofuel production to replace the use of food crops for production purposes. However current aspects and challenging issues also exists which are under study. The cellulosic ethanol produced by biotechnological sun liquid processes, when compared with ethanol manufactured from maize or wheat, boasts a hugely improved emission profile and therefore helps to minimise emission of greenhouse gases. The advantage of this process includes low production cost, flexibility in raw material as well as no requirement of fossil fuel and high yield. (Stichnothe et al., 2016)

Co-cultivation system in which combination of enzymes were used or genetically engineered to increase yield of bioethanol. Lignocellulosic material has complex cellulose degrading system and hence cannot be degraded easily by single microbial strain or if degraded then yield is much lower than required.

The anaerobic process has ability to convert the $\mathrm{COD}$ sewage into methane and $\mathrm{CO}_{2}$ and the latter being converted into microalgae in a photobioreactor process, using sunlight as energy source through a set of biochemical reaction using membrane bioreactor (Baral et $a l ., 2020)$. Due to increasing use of renewable energy in rural areas several countries has initiated the investments in bioenergy. Financial performance of agricultural companies that have undertaken bioenergy investments as the key performance indicators in energy production using agricultural waste. The investment in the bioenergy is lucrative for a company if the results obtained by it are beneficial for investors (Nurmet et al., 2019). However several researchers are studied on environmental impacts of alternative approaches to biofuel production with a focus on biodiversity and ecosystem services resulting to develop a criteria for guiding the identification of sustainable biofuel production alternatives. Strategies are also in developing stage for decreasing the economic barriers which prevent the sustainable biofuel production systems (Vaez et al., 2020). Now 
various tools have been used constantly to evaluate environmental life cycle assessment (LCA) and techno-economic analysis (TEA) which significantly impacts on algal biofuel production (Azari et al., 2020)

In conclusion the plants are integral parts of our living at variable levels for providing basic needs of human beings. Now due to urbanization and several environmental issues we need sustainable energy resources to fulfil our energy crisis. The lignocellulosic biomass is most abundant biomass produced due to various agriculture activities. Lignocellulosic agro-waste biomass has been proposed to be one of the major renewable energy production in countries where this biomass is easily available throughout the year. It can be concluded that the cellulosic biomasses pay a significant role to reduce the excessive consumption of non-renewable energy sources for energy production since energy production by using biomass is economical as well as environment friendly natural also production.

\section{References}

Ahmad, M., Khan, M. A., Zafar, M., \& Sultana, S. (2011). Biodiesel from non edible oil seeds: a renewable source of bioenergy. Economic effects of biofuel production, 259-280.

Ali, M. A., \& Hamid, H. (2004). Research Institute, King Fahd University of Petroleum and Minerals, Dhahran, Saudi Arabia. Handbook of MTBE and Other Gasoline Oxygenates, 16.

Amin, S. (2009). Review on biofuel oil and gas production processes from microalgae. Energy conversion and management, 50(7), 1834-1840.

Ananda, N., Vadlani, P. V., \& Prasad, P. V. (2011). Evaluation of drought and heat stressed grain sorghum (Sorghum bicolor) for ethanol production. Industrial Crops and
Products, 33(3), 779-782.

Azari, A., Tavakoli, H., Barkdoll, B. D., \& Haddad, O. B. (2020). Predictive model of algal biofuel production based on experimental data. Algal Research, 47, 101843.

Baral, S. S., Dionisi, D., Maarisetty, D., Gandhi, A., Kothari, A., Gupta, G., \& Jain, P. (2020). Biofuel production potential from wastewater in India by integrating anaerobic membrane reactor with algal photobioreactor. Biomass and Bioenergy, 133, 105445.

Bhattacharya, A., \& Kumar, P. (2010). Water hyacinth as a potential biofuel crop. Electronic Journal of Environmental, Agricultural and Food Chemistry, 9(1), 112-122.

Capunitan, J. A., \& Capareda, S. C. (2012). Assessing the potential for biofuel production of corn stover pyrolysis using a pressurized batch reactor. Fuel, 95, 563-572.

Çaylak, B., \& Sukan, F. V. (1998). Comparison of different production processes for bioethanol. Turkish Journal of Chemistry, 22(4), 351-360.

Correa, D. F., Beyer, H. L., Fargione, J. E., Hill, J. D., Possingham, H. P., Thomas-Hall, S. R., \& Schenk, P. M. (2019). Towards the implementation of sustainable biofuel production systems. Renewable and Sustainable Energy Reviews, 107, 250263.

Singh, A. K., Srivastava, J. K., Chandel, A. K., Sharma, L., Mallick, N., \& Singh, S. P. (2019). Biomedical applications of microbially engineered polyhydroxyalkanoates: an insight into recent advances, bottlenecks, and solutions. Applied microbiology and biotechnology, 103(5), 2007-2032.

Chandra, R., Takeuchi, H., \& Hasegawa, T. (2012). Methane production from lignocellulosic agricultural crop wastes: A review in context to second generation of biofuel production. Renewable and Sustainable Energy Reviews, 16(3), 1462-1476. 
Dagnino, E. P., Chamorro, E. R., Romano, S. D., Felissia, F. E., \& Area, M. C. (2013). Optimization of the Pretreatment of Prosopis nigra Sawdust for the Production of Fermentable Sugars. BioResources, 8(1), 499-514.

David, K., \& Ragauskas, A. J. (2010). Switchgrass as an energy crop for biofuel production: a review of its lignocellulosic chemical properties. Energy \& Environmental Science, 3(9), 1182-1190.

De Albuquerque Wanderley, A. C., Soares, M. L., \& Gouveia, E. R. (2014). Selection of inoculum size and Saccharomyces cerevisiae strain for ethanol production in simultaneous saccharification and fermentation (SSF) of sugar cane bagasse. African Journal of Biotechnology, 13(27).

Gaurav, N., Sivasankari, S., Kiran, G. S., Ninawe, A., \& Selvin, J. (2017). Utilization of bioresources for sustainable biofuels: a review. Renewable and Sustainable Energy Reviews, 73, 205-214.

Gheewala, S. H. (2012). Food, fuel and climate change: policy performance and prospects for biofuels in Thailand. Sustainable Bioenergy in Asia: Improving Resilience to High Food Prices and Climate Change, 80-89.

Hoefnagels, R., Smeets, E., \& Faaij, A. (2010). Greenhouse gas footprints of different biofuel production systems. Renewable and Sustainable Energy Reviews, 14(7), 1661-1694.

Ingale, S., Parnandi, V. A., \& Joshi, S. J. (2019). Bioethanol Production Using Saccharomyces cerevisiae Immobilized in Calcium Alginate-Magnetite Beads and Application of Response Surface Methodology to Optimize Bioethanol Yield. In Sustainable Approaches for Biofuels Production Technologies (pp. 147-181). Springer, Cham.

Jacob Teter,Pharoah Le Feuvre,Marine Gorner,SachaScheffer (IEA (2019), "Tracking Transport", IEA, Paris https://www.iea.org/reports/tracking- transport-2019)

Jain, A., \& Chaurasia, S. P. (2014). Bioethanol production in membrane bioreactor (MBR) system: a review. Int $J$ Environ Res Dev, 4(4), 387-394.

Jeslin, J., Koshy, A., Chamundeeswari, M., \& Verma, M. L. (2020). Recent Progress in Emerging Microalgae Technology for Biofuel Production. In Substrate Analysis for Effective Biofuels Production (pp. 79-122). Springer, Singapore.

Jiang, Y., Wu, R., Zhou, J. et al. Recent advances of biofuels and biochemicals production from sustainable resources using co-cultivation systems. Biotechnol Biofuels 12, 155 doi:10.1186/s13068-019-1495-7)

Katiyar, R., Kumar, A., \& Gurjar, B. R. (2017). Microalgae based biofuel: challenges and opportunities. In Biofuels (pp. 157-175). Springer, Singapore.

Kim, M., \& Day, D. F. (2011). Composition of sugar cane, energy cane, and sweet sorghum suitable for ethanol production at Louisiana sugar mills. Journal of industrial microbiology \& biotechnology, 38(7), 803-807.

Kumar, K., Ghosh, S., Angelidaki, I., Holdt, S. L., Karakashev, D. B., Morales, M. A., \& Das, D. (2016). Recent developments on biofuels production from microalgae and macroalgae. Renewable and Sustainable Energy Reviews, 65, 235249. doi:10.1016/j.rser.2016.06.055

Maiorella, B., Wilke, C. R., \& Blanch, H. W. (1981). Alcohol production and recovery. In Bioenergy (pp. 43-92). Springer, Berlin, Heidelberg.

Mitchell, R., Vogel, K. P., \& Uden, D. R. (2012). The feasibility of switchgrass for biofuel production. Biofuels, 3(1), 47-59.

Mueller, S. A., Anderson, J. E., \& Wallington, T. J. (2011). Impact of biofuel production and other supply and demand factors on food price increases in 2008. Biomass and bioenergy, 35(5), 1623-1632.

Nurmet, M., Lemsalu, K., Mõtte, M., \& 
Lehtsaar, J. (2019). Bioenergy in agricultural companies: financial performance assessment.

Olsson, L., \& Hahn-Hägerdal, B. (1996). Fermentation of lignocellulosic hydrolysates for ethanol production. Enzyme and Microbial technology, 18(5), 312-331.

Panagiotou, G., \& Olsson, L. (2007). Effect of compounds released during pretreatment of wheat straw on microbial growth and enzymatic hydrolysis rates. Biotechnology and Bioengineering, 96(2), 250-258.

Panella, L. (2010). Sugar beet as an energy crop. Sugar Tech, 12(3-4), 288-293.

Pattanaik, L., Naik, S. N., \& Hariprasad, P. (2019). Valorization of waste Indigofera tinctoria L. biomass generated from indigo dye extraction process - potential towards biofuels and compost. Biomass Conversion and Biorefinery, 9(2), 445457.

Qureshi, N., Saha, B. C., Dien, B., Hector, R. E., \& Cotta, M. A. (2010). Production of butanol (a biofuel) from agricultural residues: Part I-Use of barley straw hydrolysate. Biomass and bioenergy, 34(4), 559-565.

Rawat, I., Kumar, R. R., Mutanda, T., \& Bux, F. (2011). Dual role of microalgae: phycoremediation of domestic wastewater and biomass production for sustainable biofuels production. Applied energy, 88(10), 3411-3424.

Shen, H., Poovaiah, C. R., Ziebell, A.,
Tschaplinski, T. J., Pattathil, S., Gjersing, E.,Chen, F. (2013). Enhanced characteristics of genetically modified switchgrass (Panicum virgatum L.) for high biofuel production. Biotechnology for Biofuels, 6(1), 71.

Stichnothe, H., Storz, H., Meier, D., De Bari, I., \& Thomas, S. (2016). Development of second-generation biorefineries. In Developing the Global Bioeconomy (pp. 11-40). Academic Press.

Sun, Y., \& Cheng, J. (2002). Hydrolysis of lignocellulosic materials for ethanol production: a review. Bioresource technology, 83(1), 1-11.

Ulgiati, S. (2001). A comprehensive energy and economic assessment of biofuels: when "green" is not enough. Critical Reviews in Plant Sciences, 20(1), 71-106.

Vaez, E., \& Zilouei, H. (2020). Towards the development of biofuel production from paper mill effluent. Renewable Energy, 146, 1408-1415.

Wright, J. D., Wyman, C. E., \& Grohmann, K. (1988). Simultaneous saccharification and fermentation of lignocellulose. Applied Biochemistry and Biotechnology, 18(1), 75-90.

Zuliani, L., Frison, N., Jelic, A., Fatone, F., Bolzonella, D., \& Ballottari, M. (2016). Microalgae cultivation on anaerobic digestate of municipal wastewater, sewage sludge and agrowaste. International journal of molecular sciences, 17(10), 1692.

\section{How to cite this article:}

Vatsla Gupta, Nishant Veer Vikram Singh, Aarushi Shukla, Namita Singh, Santosh Kumar Mishra. 2020. Sustainable Biofuel Production using Lignocellulosic Biomass as a Raw Material. Int.J.Curr.Microbiol.App.Sci. 9(07): 3339-3350.

doi: https://doi.org/10.20546/ijcmas.2020.907.390 